УДК 638.124.252.2

(C) 2014

Гречка Г. М., кандидат сільськогосподарських наук

Національний науковий центр «Інститут бджільництва імені П. І. Прокоповича»

\title{
НАПРАВЛЕНЕ ВИКОРИСТАННЯ БДЖОЛИНИХ СІМЕЙ ЗІ ЗМІНЕНИМ ФІЗІОЛОГІЧНИМ СТАНОМ
}

\section{Рецензент - кандидат біологічних наук Т. М. Сфіменко}

Показано можливість інтенсифікаиії господарської діяльності бджолиних сімей із наявністю ройових ознак иляхом застосування трьох прийомів бджоловедення: перетасування гнізда, оновлення гнізда, итучний розподіл бджіл. Встановлено, щзо «оновлення гнізда» є оптимальним методом бджоловедення, щзо сприяє нормалізації фізіологічного стану сімей медоносних бджіл (від ройового до робочого), поверненню до повноцінної життедіяльності, стабілізації й ефективного використання їх ройової енертї̈ у комплексному бджільництві та збільшення продуктивності: медової-на $12 \%$, воскової-на $15 \%$.

Ключові слова: бджолині сім'ї, фізіологічний стан, роїння, перетасування гнізда, оновлення гнізда, итучний розподіл бджіл, продуктивність.

Постановка проблеми. Важливим резервом підвищення дохідності бджільництва $є$ утримання на пасіках сильних високопродуктивних сімей та повноцінне їх використання на всякому природному медозборі впродовж пасічницького сезону. Проте досить часто у вирішенні цих стратегічних питань виникають значні труднощі. За умов небагатих ресурсів нектару та впливу інших зовнішніх чинників бджолині сім'ї легко переходять із робочого фізіологічного стану у ройовий. Стихійне роїння заважає впровадженню ефективних прийомів утримання та обслуговування бджіл і своєчасного використання належних умов медозбору, що призводить до значного зниження їх продуктивності. Тому питання про контрольоване роїння, розробки та впровадження на пасіках оптимальних методів бджоловедення, що уможливлять зміну фізіологічного стану сімей медоносних бджіл (від ройового до робочого), повернення до повноцінної життєдіяльності й стабілізації продуктивності - одне 3 найактуальніших у бджільництві.

Аналіз основних досліджень і публікацій, у яких започатковано розв'язання проблеми. Роїння, як спосіб розмноження бджолиних сімей, відоме здавна. Його вивченню присвячено чимало наукових праць [1-5; 8-9]. Кожна 3 них по-своєму цінна й заслуговує уваги. Однак проблему зниження продуктивності сімей через зміну фізіологічного стану бджіл не можна вважати остаточно вирішеною [2, 9]. Ще не повністю розкриті й зовнішні та внутрішні причини цього аспекту і методи їх усунення $[1,2]$. Деякі з відомостей теж $\epsilon$ суперечливими. Поскільки у зв'язку з цим керування роїнням поки що не можна вважати надійним і гарантованим, то, очевидно, $є$ необхідність у глибшому вивченні цього процесу. Зі слів Г. Ф. Таранова (1961), боротися з роїнням так саме безглуздо, як боротися із проявами охоти у тварин. Краще використати ці природні інстинкти для блага галузі й суспільства, задля чого необхідно досконало вивчати роїння бджолиних сімей із метою постійного відбору кращого вихідного матеріалу [8]. Тому у своїй роботі ми плануємо не боротися з цим процесом, а спрямовано використати його для забезпечення інтенсифікації бджільництва шляхом застосування «оновлення гнізда» - оптимального методу бджоловедення у рійливих сім'ях бджіл. Для цього необхідно визначити заходи, що грунтуються на знаннях біологічних особливостей життєдіяльності бджіл, відповідно до місцевих медозбірних умов, узагальненні та науковому обгрунтуванні кращих прийомів раціонального використання сімей, вимушено переключених із ройового стану у робочий. Розробка технологічного методу направленого використання бджолиних сімей зі зміненим фізіологічним станом сприятиме раціональному використанню рійливих сімей бджіл української степової породи на медозборі у сучасних умовах лісостепової зони та стабілізації основної продуктивності як окремих пасік, так і галузі загалом.

Мета і завдання досліджень. Мета: оптимізувати прийом раціонального використання бджолиних сімей у ройовому стані.

Завдання: порівняти характер фізіологічного стану, розвитку та продуктивності збуджених роїнням бджолиних сімей за різних технологічних прийомів догляду: перетасування гнізда, оновлення гнізда, штучне розділення бджіл.

Методика проведення досліджень. Дослідження проводили на одному 3 тічків пасіки ННЦ «Інститут бджільництва імені П. І. Проко- 


\section{СІЛЬСЬКЕ ГОСПОДАРСТВО. ТВАРИННИЦТВО}

повича». Вони включали досліди, що виконувалися на сорока бджолиних сім'ях української степової породи, розподілених по п'яти групах, iз яких одна - контрольна і чотири - дослідні. У контрольну групу ввійшли сім'“і з робочим фізіологічним станом, у чотири дослідні - 3 явними ознаками збудження ройового стану.

У бджолиних сім'ях першої дослідної групи застосовували один із технологічних прийомів бджоловедення, названий нами «перетасування гнізда». Для цього гніздо поділяли на два нерівних відділення перегородкою 3 умонтованою у ній роздільною решіткою. Матку залишали на засіяному стільнику біля роздільної решітки у відділенні з льотком, у якому гніздо формували ще 3 трьох рамок маломедної суші й такої ж кількості вощини. Останні розміщували навпроти льотка. Всі інші розплідні стільники переставляли за перегородку з роздільною решіткою у порядку вікового зростання після двох навощених рамок. До них підставляли навощену рамку, медово-перговий стільник і заставну дошку (початкова позиція розміщення щільників). Решту кормових стільників переносили у спільну для обох відділень надставку. Верхню частину гнізда, в якій знаходилася матка, під надставкою, прикривали стелькою 3 роздільної решітки. Вільний простір надставки заповнювали навощеними рамками й, у міру з'явлення, - повномедками $з$ безматкової частини гнізда. Позицію розміщення стільників у бджолиній сім’ї кожні 12 днів обновляли ідентично початковій.

У бджолиних сім'ях другої дослідної групи застосовували метод «оновлення гнізда». Для цього ввечері, після закінчення льоту бджіл, відловлювали у кліточку Титова матку. Гніздо зміщували до протилежної бокової стінки вулика (безльоткової) й обмежували заставною дошкою. Звільнений простір заповнювали порожніми рамками (без вощини й стільника), між двома 3 яких ставили кліточку 3 маткою. Зі зміщених стільників струшували всіх бджіл. Звільнені від бджіл стільники роздавали іншим сім'ям. Як тільки бджоли починали будувати «язики», замінювали порожні рамки на рамки з вощиною.

У бджолиних сім'ях третьої дослідної групи проводили штучне роїння, вимушено відділяючи бездіяльних ройових бджіл від робочих [8].

У сім'ях четвертої дослідної групи допускали природне роїння. У бджолиних сім'ях контрольної групи проводили звичайний догляд. Як у контрольній, так і у дослідних групах упродовж сезону проводили спостереження за станом бджолиних сімей. Показники господарськи корисної діяльності визначали методами обліку, зважувань і підрахунків [7]. Отримані результати статистично обробляли [8].

Результати досліджень. Застосування всіх трьох прийомів бджоловедення у сім'ях бджіл із ройовими ознаками $є$ цілковито правильною дією на шляху спрямування зміни їх фізіологічного стану $з$ ройового у робочий.

Застосовуючи прийом перетасування гнізда, нами було відмічено, що перед роздільною решіткою у місці перебування матки завжди скупчувалося більше бджіл, аніж у протилежній частині вулика. За цих умов комахи швидко та якісно відбудовували підставлену їм штучну вощину, у відбудовані комірки якої матка інтенсивно відкладала яйця. Вже через два обліки у маточній частині гнізда всі стільники були відбудовані. Бджоли відбудовували також вощину у берматочній частині гнізда та у надставці. Даний факт, iз біологічної точки зору, можна пояснити тим, що бджоли намагалися заповнити порожню площину, що перешкоджала їх повноцінній роботі. Так комахи реагували на наші дії, сигналізуючи про перехід із бездіяльного ройового стану в активний робочий.

Для «оновленням гнізда» характерним $є$ те, що залишена без гнізда сім'я відразу зреагувала на просторову порожнину у своєму помешканні й на третю добу відбудувала «язики» на брусках раніше порожніх рамок. Після підстановки замість них навощених рамок бджоли швидко почали їх відбудовувати - й за чотири дні повністю відновили гніздо. У комірках відбудованих стільників було виявлено яйця, личинки, мед і пергу. Під час наступних обліків відмічено інтенсивний розвиток i продуктивність сімей цієї групи.

За штучного відділення 3 рійливих сімей бездіяльних бджіл від працюючих відмічено, що цей процес $є$ досить трудомістким і довготривалим. Струшувати бджіл із рамок довелося неодноразово, допоки всі бджоли, які обсиджували стільники у вулику, після струшування зібралися гроном під дошкою сходнів. Середня маса зібраного грона склала 1,4 кілограма. У материнську сім'ю пізно ввечері підсадили плідну матку, виведену 3 ройового маточника. Наступного дня матка вже відкладала яйця, проте активність роботи сім'ї відновлювалася поступово. Підставлену вощину бджоли відбудували на дев'ятий день. 3 початком активного медозбору з еспарцету бджолині сім'ї більше не роїлися. Аналізом результатів дії з нормалізації стану сімей виявлено досить цікаві, з біологічної точки зору, відмінності щодо характеру репродуктивного поводження бджіл у цей період. Бджолині сім’і, в 


\section{СІЛЬСЬКЕ ГОСПОДАРСТВО. ТВАРИННИЦТВО}

яких перетасували гнізда (дослідна перша група), порівняно з контрольною групою, мали більшу силу на 12,62 \% (P<0,01). I, навпаки, відносно контролю мали меншу силу на $19,51 \%$ (Р<0,01) сім’і другої дослідної групи, на 21,57\% $(\mathrm{P}>0,001)$ - третьої та на $30,58 \%(\mathrm{P}>0,001)-$ четвертої дослідної групи.

Особливої уваги варті показники числа розплоду, нарахованого у піддослідних сім'ях, у сумі за три обліки перед медозбором.

Порівняно $з$ контрольною групою, у дослідних групах бджолиних сімей виявлено збільшення кількості печатного розплоду на 34,59\% (P > 0,001) - у першій, на 39,74 \% (P > 0,001) - у другій, на 20,58 \% (P > 0,001) - у третій та на $19,67 \%$ (P > 0,05) - у четвертій. Такі результати вказують на цінну біологічну особливість бджіл. Вочевидь, за ройового збудження, накопичивши у своєму тілі достатню кількість необхідних для його повноцінного функціонування упродовж життєдіяльності поживних, біологічно активних речовин і відпочивши (завдяки створеній унаслідок цього паузі від виховання розплоду) вони, подібно зимовим бджолам, отримали здатність омолодити свій організм. У зв'язку 3 цим могла збільшитися тривалість їх життя і покращитися фізіологічний розвиток. Дана гіпотеза потребує додаткових досліджень. На даному етапі вона може підтверджуватися присутністю у сім'ї, яка роїться, досить великої кількості бджіл із добре розвиненими яїчниками, про що згадує у своїх працях Ф. А. Тюнін [7].

Виходячи 3 попередніх міркувань, ми можемо й далі стверджувати про те, що у нашому випадку бездіяльні бджоли, які з'явилися у сім'ях у процесі роїння, набравшись сил і залишившись фізіологічно молодими, стабілізували свою по- тенційну енергію для майбутнього використання у новостворених умовах.

Застосовані нами у родинах із ознаками роїння досліджувані прийоми бджоловедення, кожний по-своєму, посприяли нормалізації стану сімей бджіл (поверненню з ройового до робочого) і раціональному використанню їх продуктивного потенціалу на медозборі та воскобудуванні (див. табл.).

Наведені у таблиці дані валового виробництва меду свідчать про високий рівень інтенсивності використання медозбірних умов у місцях розміщення пасіки. За слабкої та середньої мінливості маси облікованого у гніздах меду різниця між порівнюваними середніми арифметичними є неімовірною. Водночас вищими за кількісний показник меду, зібраного бджолиними сім'ями контрольної групи, були результати медопродуктивності родин дослідних груп, зокрема: на $9,8 \%$ - першої і на $12,41 \%$ - другої i, у той же час, нижчими на 1,31 \% від третьої та на 14,37 \% - четвертої дослідних груп. Порівнюючи результати продуктивності сімей дослідних відмічаємо, що хоч і з невеликою перевагою, але все ж найбільше меду заготовили бджолині сім'̈, у яких під час ройового збудження був застосований прийом «оновлення гнізда» (друга група) і найменше - бджолині сім’ї, в яких було допущено природне роїння.

За результатами наших попередніх досліджень, зниження воскової продуктивності бджолиних сімей через роїння становить $40 \%$.

Шляхом використання планових прийомів бджоловедення, що зумовили нормалізацію фізіологічного стану бджіл, ми також цілеспрямовано спонукали сім'ю до покращання (після цього) будівельної роботи.

Продуктивність бджолиних сімей упродовж сезону

\begin{tabular}{|c|c|c|c|c|c|c|c|c|}
\hline Групи бджо- & \multicolumn{4}{|c|}{ Мед валовий, кг } & \multicolumn{3}{c|}{ Відбудовано стільників, шт. } \\
\cline { 2 - 9 } линих сімей & $\mathrm{M} \pm \mathrm{m}$ & $\mathrm{Q}$ & $\mathrm{CV}$ & $\mathrm{t}_{\mathrm{d}}$ & $\mathrm{M} \pm \mathrm{m}$ & $\mathrm{Q}$ & $\mathrm{CV}$ & $\mathrm{t}_{\mathrm{d}}$ \\
\hline Контрольна & $51,0 \pm 2,65$ & 4,58 & $8,98 \bullet \bullet$ & - & $9,7 \pm 0,58$ & 0,58 & $5,97 \bullet \bullet$ & - \\
\hline $\begin{array}{c}\text { Дослідна } \\
\text { перша }\end{array}$ & $56,0 \pm 1,16$ & 2,00 & $3,57 \bullet$ & 1,73 & $11,0 \pm 0,58$ & 1,00 & $9,09 \bullet \bullet$ & 1,98 \\
\hline Дослідна друга & $57,3 \pm 1,76$ & 3,06 & $5,33 \bullet$ & 1,99 & $11,1 \pm 0,45$ & 0,76 & $6,84 \bullet \bullet$ & 2,00 \\
\hline Дослідна третя & $50,3 \pm 2,19$ & 3,79 & $7,52 \bullet \bullet$ & 0,20 & $10,3 \pm 0,88$ & 1,53 & $14,79 \bullet \bullet$ & 0,70 \\
\hline $\begin{array}{c}\text { Дослідна } \\
\text { четверта }\end{array}$ & $43,7 \pm 2,91$ & 5,03 & $11,53 \bullet$ & 1,87 & $8,5 \pm 1,04$ & 1,80 & $21,21 \bullet \bullet$ & 1,07 \\
\hline
\end{tabular}

Примітка: • - слабка мінливість ознаки; •• - середня мінливість ознаки; ••• - сильна мінливість ознаки (по відношенню до бджолиних сімей контролю, які взагалі не входили у роїння і впродовж пасічницького сезону мали незмінно робочий фізіологічний стан) 


\section{СІЛЬСЬКЕ ГОСПОДАРСТВО. ТВАРИННИЦТВО}

3 цією метою намагалися через забезпечення бджіл великим і довготривалим медозбором створити умови для інтенсивної репродукції. В організованих медозбірних умовах сім'ї приносили у середньому за день близько 0,8 кг корму. Бджоли отримали можливість добре розвиватися, що сприяло інтенсивному медозбору та будуванню стільників.

Відносно кількісного показника стільників відбудованих бджолами контрольної групи одержані результати дослідних груп вищі на $13,75 \%$ - у першій, на $15,20 \%$ - у другій, на $6,83 \%$ - у третій та нижчі на $12,1 \%$ у четвертій групі.

Бджолині сім'ї четвертої дослідної групи, які були допущені до роїння, зроїлися 22 та 23 травня. Рої були поселені у нові вулики. У материнських сім'ях під час наступного чергового обліку знову виявили маточники. Надалі їх зривали, щоб відтягнути період повторного роїння. 3 початком щедрого медозбору з еспарцету бджоли вже самі знищили маточники й переключилися на збір нектару та пилку. До кінця сезону роїння на пасіці більше не спостерігалося.

Таким чином, догляд бджолиних сімей у разі

\section{БІБЛІОГРАФІЯ}

1. Бабич I. А. Важлива причина роїння бджіл / I. А. Бабич // Бджільництво. - К. : Урожай, 1964. - C. 8-23.

2. Билаш Г. Д. Изучение ройливости и особенностей проявления роевого инстинкта / Г. Д. Билаш // Селекция пчел. - Изд-во «Московский рабочий», 1965. - С. 8-60.

3. Гиниятуллин М. Г., Иимуратова Н. М. Сравнительная оценка аттрактантов для пчелиных роев / М. Г. Гиниятуллин, Н. М. Ишмуратова // Пчеловодство. - 2003. - №3. - С. 16-17.

4. Кияшко М. Про зимівлю та роїння / М. Кияшко // Пасіка. - 2003. - №9. - С. 8-9.

5. Корж В. Н. Роение пчел: причины и пред- рійливості передбачає врахування біологічних особливостей, що забезпечують фізіологічно злагоджений взаємозв'язок між особинами всіх стаз медоносних бджіл на різних етапах процесу. Процес роїння бджолиних сімей піддається керуванню шляхом врахування внутрішніх (біологічних) і регулювання зовнішніх (технологічних) чинників, що передують зміні фізіологічного стану.

\section{Висновки:}

1. Для нормалізації фізіологічного стану сімей медоносних бджіл (від ройового до робочого) i раціонального використання їх продуктивного потенціалу на медозборі та воскобудуванні в умовах Лісостепу України із трьох можливих прийомів бджоловедення рійливих сімей української степової породи оптимально найкращим $\epsilon$ «оновлення гнізда».

2. Метод «оновлення гнізда», застосований у бджолиних сім'ях під час роїння, забезпечує безповоротну зміну їх фізіологічного стану з ройового у робочий та збільшення (у середньому на гніздо) кількості зібраного меду на $12 \%$ та відбудованих стільників - на $15 \%$.

упреждение / В. Н. Корж. - Харьков : Антиква, 2001. $-90 \mathrm{c}$.

6. Лакин Г. Ф. Биометрия / Г. Ф. Лакин. Минск : Высшая школа, 1980. - 293 с.

7. Практикум з основ наукових досліджень у тваринництві : [навч. видання для студ. вищих навч. закл.] / В. К. Кононенко, І. І. Ібатуллін, В. С. Патров - К. : Ірена, 2003. - 133 с.

8. Таранов Г. Ф. Биология пчелиной семьи / Г. Ф. Таранов. - М. : Сельхозиздат, 1961. - 236 с.

9. Чергик М. I. Вплив роїння на медозбір. Весняний розвиток бджоли / М. І. Чергик // Пасіка. 2003. - №3. - C. 8-9. 